DOI: 10.20472/TEC.2017.004.007

ELSA MENTZ

North-West University, South Africa

JOSEF DE BEER

North-West University, South Africa

\title{
THE AFFORDANCES OF CULTURAL-HISTORICAL ACTIVITY THEORY AS A RESEARCH LENS IN STUDYING EDUCATION FROM A SOCIO-ECONOMIC PERSPECTIVE
}

\begin{abstract}
:
In this paper the authors look at Cultural-Historical Activity Theory (CHAT) as a lens to study education from, not only a socio-cultural perspective, but also from a socio-economic perspective. CHAT has its origin in the work of Lev Vygotsky. It takes as a starting point that human practice is mediated by tools or signs. The unit of analysis is an activity system and, in this paper, several activity systems are used as examples to illustrate the use of CHAT. The examples used are not based on specific empirical data, but on selected literature, since the focus of this paper is to highlight the affordances and versatility of CHAT as a research lens. Rogoff stated that three planes, namely the personal, the interpersonal, and the institutional or community plane might be identified in a socio-cultural analysis using CHAT. Conventionally CHAT is used as a research lens on the personal plane, where the subject is an individual, for example, a science teacher, and the object is this teacher's professional development. Secondly, CHAT can also be used on an interpersonal plane, looking at the interaction between various stakeholders. In this article the authors look at the changing nature of the interaction between university lecturers (facilitators) and tertiary students as an example of the use of CHAT on the interpersonal level. It is particularly on this interpersonal plane that this paper highlights the complexity of the "object" in an activity system, by revealing the "contradiction of control". Rogoff identifies a third way of using CHAT, namely where the subject is a system or a theory. In this paper, we conclude with two examples of how CHAT can be used on this more systematic-theoretical plane, with the subject being South African and Finnish education respectively. This is an approach seldom used in activity theory publications. By learning from the international "gold standard" in education (Finland) South Africa might succeed in improving its education, which can, in turn, catapult economic growth. We conclude this paper by looking at the \#FeesMustFall student campaign in South Africa, where we juxtapose university management's perceptions and expectations, with that of student bodies. The authors argue that the holistic view that CHAT provides on tensions within activity systems is essential in educational research in a complex 21st Century. Educational issues such as the \#FeesMustFall is not simply a South African issue of concern, but a contemporary issue in a post-colonial world.
\end{abstract}

\section{Keywords:}

Cultural-Historical Activity Theory; South African education; science education; self-directed learning; transformation; South African students' \#FeesMustFall campaign.

JEL Classification: 125,123 


\section{Introduction: South Africa as "the crucible"}

In their book, "The crucible: Forging South Africa's future", Beck and Linscott (1991:13) stated that: "All the world's collective ills (racism, ideologies, unscrupulous exploitation and oppression) have been twisted and compressed into this southern region of Africa... Yet something is being created in the turmoil and chaos of the crucible which is South Africa... Its society may well be on the brink of a series of innovative breakthroughs which offer promise to the rest of the planet". Beck and Linscott's work focus mainly on value systems. These authors describe the South African diversity in the following way: "While certain minds are at home with space-age technology, others are just joining the agricultural or industrial revolution" (Beck \& Linscott, 1991:20). Their concept of "memes" (value systems that shape thinking and behaviour) explains the diversity of South Africans and their values. Whereas some South Africans treasure the indigenous and cultural ways of doing (the purple meme) where the focus is on co-operation rather than individual performance, other South Africans may favour what Beck calls the turquoise meme, which signifies a global community or holistic focus on the well-being of all entities. A better example still of a contrasting meme would be the orange meme, which can be characterised by materialistic values, and economic empowerment of the individual. This is in sharp contrast to the collective sentiments of the purple meme. The same disparity is found in South Africa's schools. Whereas some private schools in the country are on par with the finest schools in the world, others (especially in rural areas) can be described as dysfunctional.

In Higher Education in South Africa the situation is not much different. Tensions often exist between university management and student bodies on, for example, tuition fees and the content of the curriculum. De Beer, Smith and Jansen (2009) have shown that university students sometimes show a lack of trust in management, and often engage in an "us" versus "them" discourse. The violent \#FeesMustFall student campaign in 2016, which resulted in many South African university campuses closing down for several weeks, demonstrated dissatisfaction with educational reform, as well as mistrust in university management. On the other hand, it also contributed to growing economic deterioration as infrastructure was destroyed at universities across the country. The question can be raised as to whether the \#FeesMustFall campaign will not contribute to more qualified people without jobs; the lowering of standards at universities as a result of the inability of the government to provide more financial support to universities; and an increased burden on the public treasury (due to the destruction of property, which amounted to multi-million Dollars in 2016), to name a few. Such complex situations that plague education is what makes Cultural-Historical Activity Theory (CHAT) such a powerful research lens in the South African context, as it takes the historical, cultural and socio-economic context of the country into consideration when studying education. This approach of taking the holistic context into consideration holds promise to assist researchers in proposing solutions to the myriad of educational problems. In this paper we'll attempt to show, through four 
examples, how CHAT is a useful lens for the analysis of complex activities systems such as the South African education system, and a way to gain insight into the different tensions visible in an activity system.

\section{CHAT as a research lens}

Cultural-Historical Activity Theory (CHAT) has its origin in the work of Lev Vygotsky. CHAT takes as a starting point that human practice is mediated by tools or signs. Vygotsky (1978) emphasized the value of psychological tools (signs) such as language, models and theories (Havnes, 2010). CHAT considers human psychological functioning as embedded in culture and history. The unit of analysis is therefore always the person in context (Havnes, 2010), that is, the person imbedded within an activity system. An activity system is a concept of Engeström, a prominent researcher in the Vygotskyan tradition (together with researchers like Leot'ev, Luria and Veresov), and it assists the researcher to understand how people are embedded in a sociocultural context with which they continuously interact. Such an activity system comprises the object of the activity; the subject involved in the activity; tools relevant to the activity; rules that shape participation in the activity; the community (all the stakeholders involved in the activity system); and lastly the division of labour entailed in carrying out the activity. Vygotsky's colleague Luria (1981:25) explained it as such: "In order to explain the highly complex forms of human consciousness one must go beyond the human organism. One must seek the origins of conscious activity...in the social and historical forms of human existence" (cited by Wertsch, 1998:8). Vygotsky stated that the development of higher psychological functions implies the mastery of processes that are social - that are external before they become internal. The CHAT lens makes provision for a specific gaze into the activity system - looking for an acting subject, an object of activity, tools and signs used in mediating activity, rules for the system, the community in the system, and the division of labour in the system, as shown in Figure 1.

CHAT is a lens that is used to gain more insight from empirical data. This paper, although it draws from a selected body of research literature, does not focus on a specific data set, since its goal is to showcase the affordances and versatility of CHAT as a research tool. In addition, the authors do not attempt to draw any conclusions or make recommendations on the data presented, due to the particular leitmotiv of this paper.

\section{Conventional use of CHAT as research lens: The personal plane}

To better contextualize our first exemplar of CHAT use, we need to focus on the connection between science education and economic growth in a country. In order to be a global player in the world economy, South Africa needs innovative, creative scientists and engineers. One key solution to this problem is the drastic improvement 
of mathematics and science education in schools. According to a research report produced by the Centre for Development and Enterprise (CDE, 2011) the failure to improve mathematics and science education is one of the most significant obstacles to advancement and economic growth in South Africa.

Normally CHAT is used as a research lens on the personal plane. In Figure 1 we demonstrate how CHAT could be used in such a way. One of the big challenges facing South Africa is to break the predominant "transmission-mode" teaching in school classrooms, and replace it with problem-based approaches (De Beer \& Ramnarain, 2012) and skills development to enable learners to meet the challenges of the $21^{\text {st }}$ Century. Such a focus on problem-based learning could also foster the development of self-directed learning. Both authors are of the opinion that the fostering of self-directed learning should be a national priority in South Africa. This dictates a change in how teaching and learning is approached in the classroom. In Figure 1 the authors provide one perspective on the use of CHAT as a lens to focus on improving science education in South Africa through effective teacher professional development. We will revisit this aspect in the third example (Figure 4), where the real state of science education in the country will be compared with an effective education system such as that of Finland.

\section{Figure 1: CHAT on the personal level}

TOOLS
Pedagogy (active learning strategies);
laboratories (open-ended inquiries) and

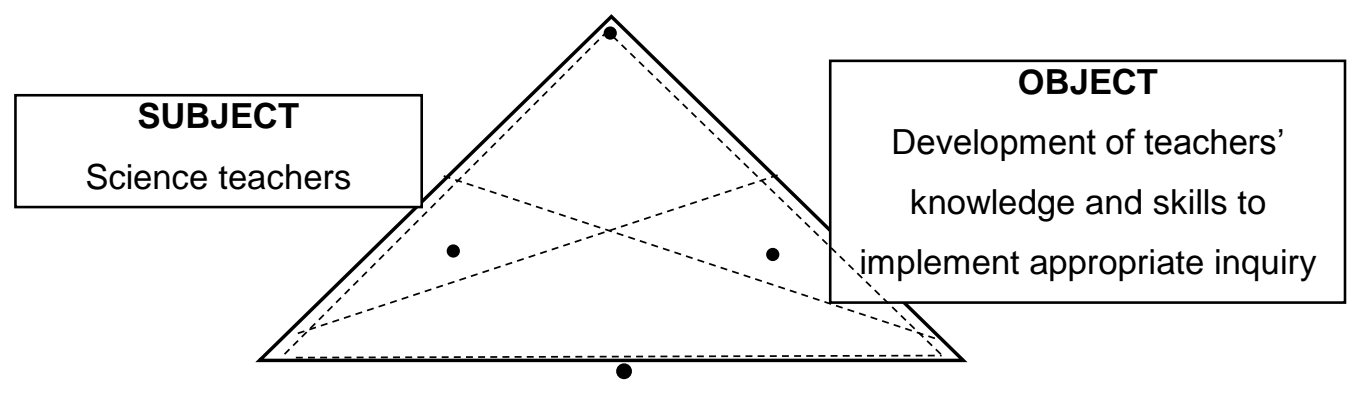

\begin{tabular}{|c|}
\hline RULES \\
The principles of active \\
learning strategies \\
The curriculum guidelines \\
Tenets of the Nature of \\
Science \\
Classroom atmosphere \\
\hline
\end{tabular}

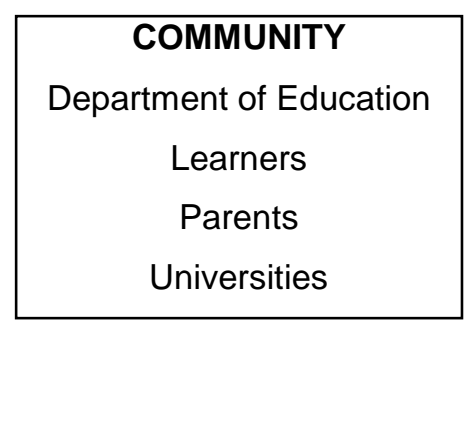

DIVISION OF LABOUR

The teacher as a:

Facilitator

Self-directed learner

Agent of change

Critical reflective practitioner 
Figure 1 depicts an activity system for teacher professional development. The science teacher is seen as the subject, and the object is the teacher's professional development in terms of knowledge and skills to implement appropriate inquiry, problem-solving and cooperative approaches, especially related to a better understanding of the tenets of science, and which could foster self-directed learning. Tools that would enable a teacher to follow such approaches would include the skill to facilitate active-learning strategies, as well as sufficient facilities and resources such as laboratories and materials which enable learners to learn about the nature of science through open-ended inquiry. Rules refer to all the imperatives, guidelines and instructions that influence the activity. The South African curriculum document emphasizes active learning strategies such as problem-based learning, and science teachers should have the ability to emphasize the tenets of science in their classes through the implementation of these strategies. Abd-El-Khalick, Bell and Lederman (1998) mention the assumed relationship that exists between teachers' views on science and how they teach. It is therefore of the utmost importance, if the tenets of science are to be promoted through active learning strategies, that teachers have a good understanding of the tenets of science. A supportive community is needed. For instance, both the school management and the Department of Education should work towards establishing well-functioning communities of practice that could support teacher professional development. Under division of labour the various roles of the teacher are examined: apart from being a facilitator of learning, a teacher should also be a self-directed learner (taking responsibility of their own learning, keeping abreast of developments in his/her subject), a critical-reflective practitioner, as well as an agent of change, who could address problems in creative and innovative ways according to the demands of the $21^{\text {st }}$ century, and the unique culture, historical background and context in which learning take place.

The above example of a CHAT gaze on an activity system, is an overly optimistic look, and in Figure 4 a more realistic focus on science education in South Africa will be provided. However, we wanted to show with this example how CHAT can elucidate an activity system where the focus is on the personal level. Although the use of CHAT on the personal level highlights inherent tensions in the activity system, it does not offer the same insights into the complexity of South African education as when at least two juxtaposed activity systems are used as the unit of analysis, as will be discussed in the next examples.

\section{The use of CHAT on an interpersonal plane}

Beatty and Feldman (2009) used CHAT in a rather unconventional way, where the subject was the teacher, and the object was the students and their knowledge. Although this approach has its merits, it also holds the handicap of possible oversimplification of a complex activity system. We personally subscribe to Engeström's (2009:24) view, that "in today's interconnected world, it is often useful to take two interdependent activity systems as the minimal unit of analysis". Such a stance would 
mean that two interdependent activity systems are juxtaposed. Engeström uses the metaphor of "weaving together", and argues that context is constructed by fibres or threads of action which become intertwined. In practical terms: any classroom is characterized by at least two activity systems: (a) the school-going activity of the students, and (b) the teaching activity of the teachers. They ideally work together towards a common goal. Figure 2 shows how Beatty and Feldman looked at the interaction between teacher and learner, in the classroom as an activity system.

\section{Figure 2: CHAT on an interpersonal plane}

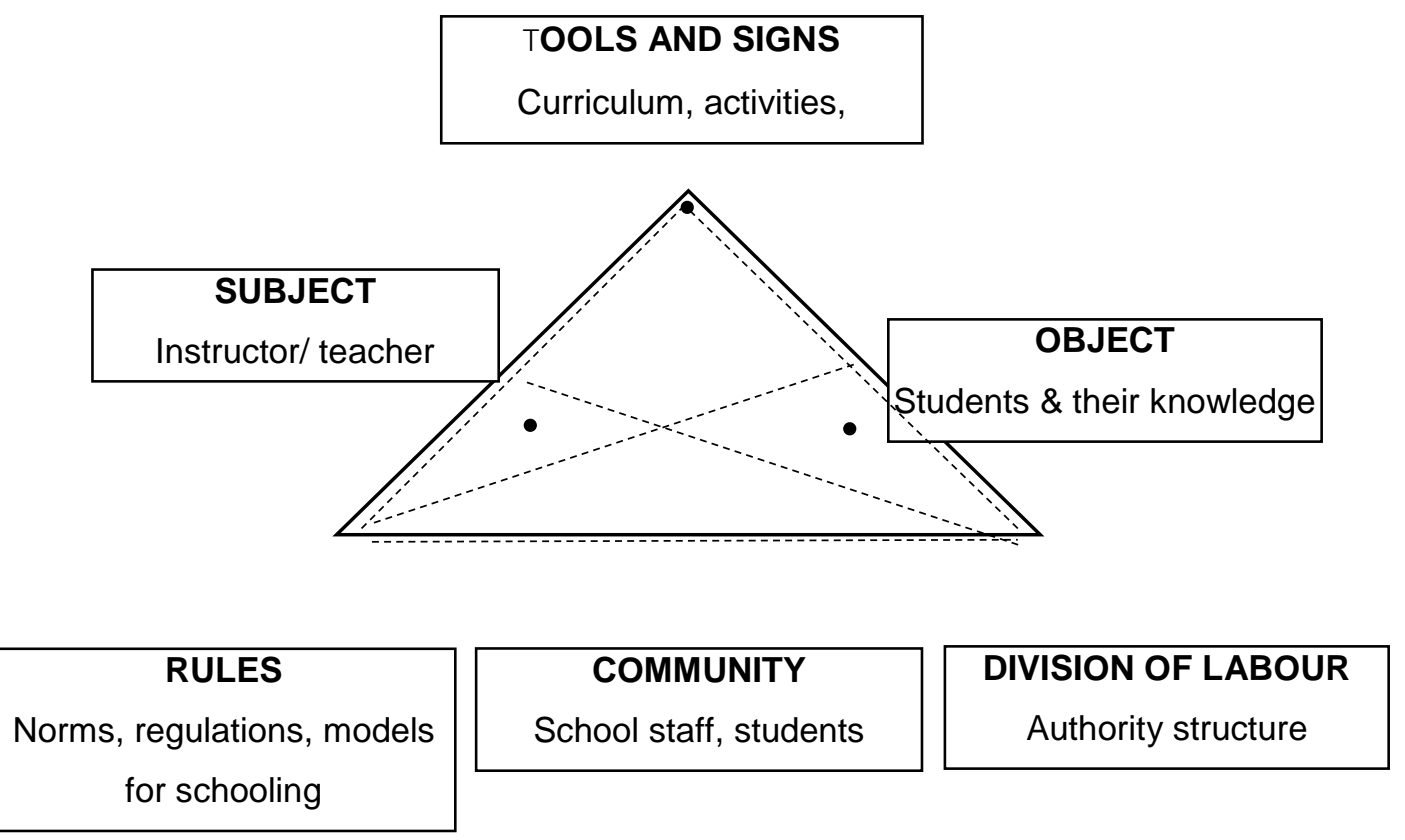

Source: Beatty and Feldman (2009:19)

Our approach to achieving an interpersonal plane focus, is to take two sub-activity systems (namely the teaching activities of the lecturer or facilitator, and the learning activities of students, which are, of course, interconnected), as unit of analysis, as depicted in Figure 3. 
Figure 3: CHAT on interpersonal level: Fostering self-directed learning in students

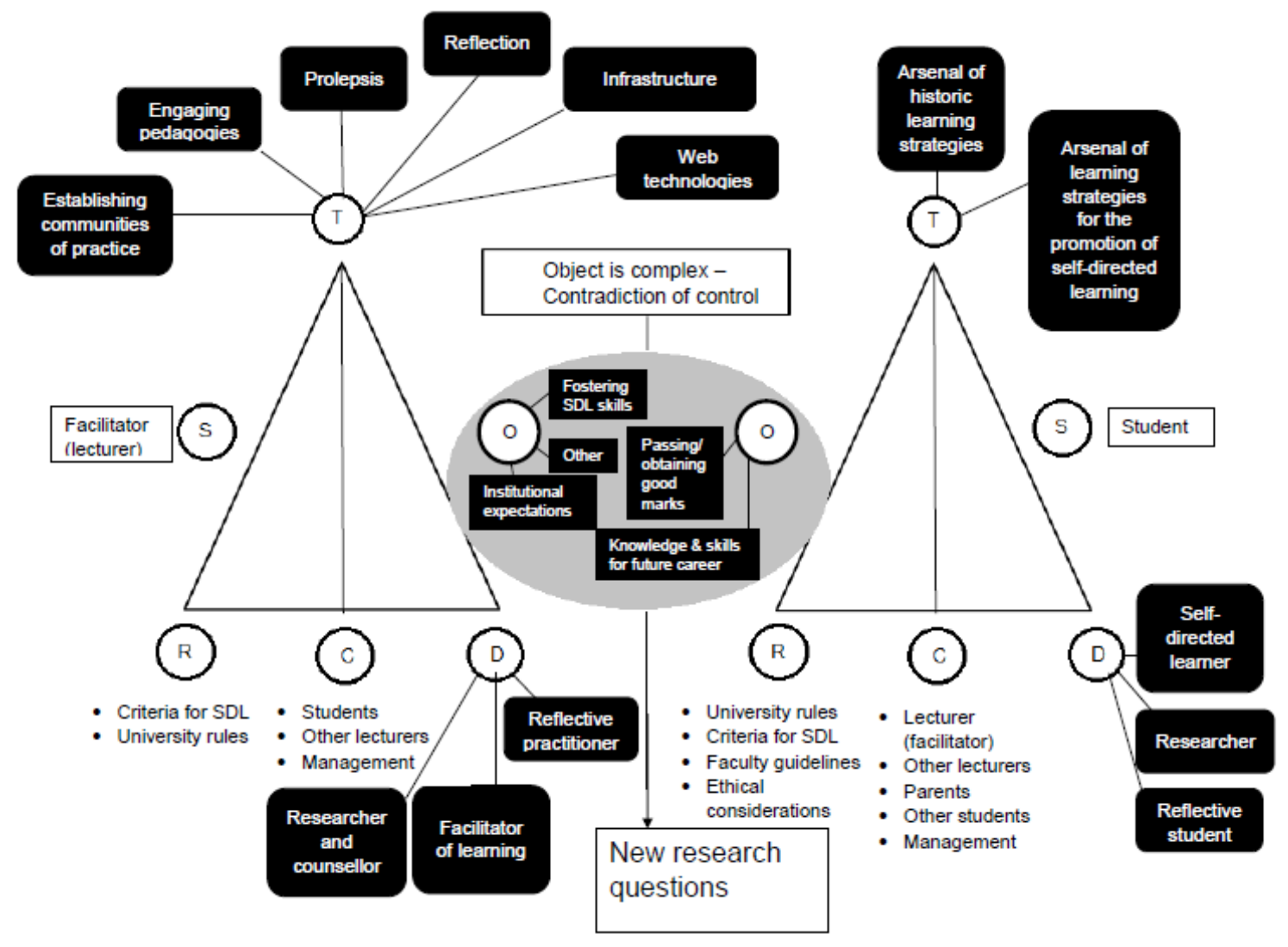

Source: Authors' own example, based on third-generation CHAT as developed by Engeström (2009)

In Figure 3 we provide an example of CHAT on an interpersonal plane to foster selfdirected learning. The facilitation function of the facilitator or lecturer is seen as one sub-activity system. This should be understood in the light of Reitsma, Guglielmino and Mentz's (2012) stance that the role of the teacher (facilitator) should shift first from teaching specified content to the facilitation of learning; and then, in a second shift, to assist students to locate and evaluate information among the almost endless amount of information available. Of importance to Reitsma, Guglielmino and Mentz is the need to promote self-directed learning among students in order to prepare them for a challenging $21^{\text {st }}$ century. Instead of being the traditional "sage on the stage", the teacher should become the "guide on the side". This is easier said than done as people do not like change, and years of teaching practice and experience cannot easily make way for new approaches.

Engeström (2009) mentions that an activity system is built around its object. McNeil (1999) refers to the "contradiction of control", which sheds light on the complexity of the object in an activity system. In Figure 3, it is clear that a unified or shared object is not always present in an activity system. The object as seen from the lecturer's (or 
facilitator's) perspective could be to foster self-directed learning skills in students. This has a direct influence on the tools that the lecturer would choose (e.g. pedagogies based on problem-based and cooperative learning). A lecturer mindful of the necessity to foster self-directed learning aptitudes and skills, will be guided by the literature on self-directed learning and the principles underpinning cooperative learning, problembased learning, etc. However, McNeil's "contradiction of control" refers to how the nature of the institution or institutional expectations could set up barriers that could hinder the fostering of self-directed learning. One example would be the practice of an institution requiring detailed learning guides explicitly listing learning outcomes; steps that should be taken by the student to achieve these outcomes; resources that should be used; and a rigid and strict assessment policy. This might not foster self-directed learning. The challenge is for a lecturer to develop learning guides that are true to Knowles's (1975) classic definition of self-directed learning: "In its broadest meaning self-directed learning describes a process by which individuals take the initiative, with or without the assistance of others, in diagnosing their learning needs, formulating learning goals, identifying human and material resources for learning, choosing and implementing appropriate learning strategies, and evaluating the learning outcomes". This is an example where CHAT illuminates an internal conflict within the facilitator.

The student might desire good marks (eventually obtaining a qualification) as the object, thus highlighting the exchange value of the learning (Engeström, 2009). However, the students might also see the potential usefulness of the knowledge, in providing them with skills needed in the $21^{\text {st }}$ Century (use value of the learning). Once again CHAT highlights internal conflict within the student. Obviously there is also conflict in the respective views of facilitators and students in terms of the object.

As Engeström (2009:24) points out, the construction of a shared object in an activity system, with such colliding perspectives, is a challenge. Figure 3 highlights the complexity of such an activity system, as several lecturers (facilitators), all with different views and understanding of self-directed learning, teach the same students, which further contributes to the complexity of the object.

One of the contributions of this paper is that we propose two juxtaposed sub-activity systems, focusing respectively the lecturer (facilitator) and the student as subjects of the two sub-systems, rather than the more direct approach proposed by Beatty and Feldman (2009). Our method of using CHAT on an interpersonal plane highlights the complexity of the object by revealing the contradiction of control. It is important that lecturer (facilitator) and student share a common object. Engeström (2009:24) states that the construction of a shared object and common motive between activity systems with such colliding perspectives is a challenge, never completely achieved and never completely impossible. The new insight into the complexity of the object could lead to the formulation of new research questions (see Figure 3). In Figure 4 and 5 we will provide more examples, of the complexity of the object in an activity system, by focusing on the use of CHAT on an institutional plane. 


\section{The use of CHAT on an institutional plane}

We have already referred to the opinion of the Centre for Development and Enterprise that South Africa's economic growth is restricted by its poor state of education. To demonstrate the third application of CHAT, namely its use on the institutional plane, we have therefore decided to compare South African education to a country that is seen as the "gold standard" in science education due to its excellent performance in international benchmark tests like PISA and TIMSS - Finland. We visually represent this in Figure 4. In this example the subject is not a person, but an institution or system- in this particular case Finnish and South African education. This particular application also demonstrates another use of CHAT, namely comparing best practice to activity systems with inherent weaknesses.

Whereas Finland occupies top positions in international tests, South Africa's performance in TIMSS leaves much to be desired. According to the Global Competitiveness Report (2010-2011), South Africa ranked $137^{\text {th }}$ out of 139 countries in quality of mathematics and science education. We concur with the 2007 McKinsey study that clearly highlights that no schooling system can rise above the limits imposed by the quality of its teachers. We therefore see the quality of mathematics and science teachers as key to addressing the dismal performance of South African learners in international benchmark tests.

Figure 4: Comparing science education in South Africa and Finland (respectively the subject in the two activity systems)

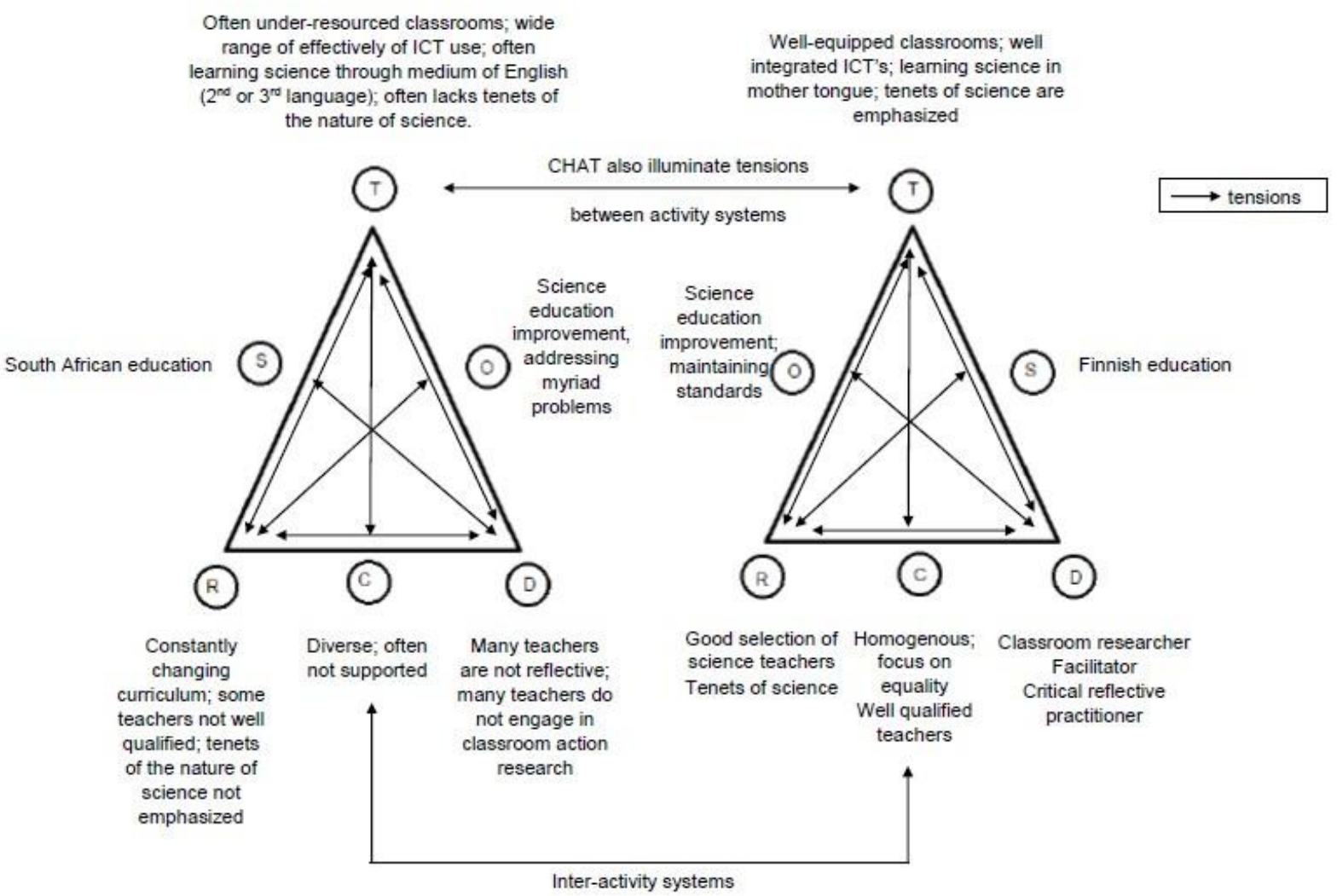

Source: Authors' own example, based on third-generation CHAT as developed by Engeström (2009) 
We would like to return to the metaphor of a crucible used earlier. Finland is a very homogenous country. In Finland $95 \%$ of the population speaks Finnish and the other $5 \%$ Swedish. Most of the students are, therefore, taught science in their mother tongue. This is in sharp contrast to the South African situation, where most students are taught science through the medium of English, which is most often their second or third language. South Africa has eleven official languages, and much cultural diversity. Cultural differences place a big burden on teachers as they strive to ensure that science is well contextualised, so that learners can relate to it. This is one of the affordances of Cultural-Historical Activity Theory: it provides a lens that take cultural and historical factors into consideration, and highlights the complexities inherent in activity systems.

Not all teachers in South Africa are well qualified. Many South African science teachers lack the necessary pedagogical content knowledge to teach science effectively and the envisaged open-ended inquiry as stated in the national curriculum in South Africa is often replaced by transmission-mode teaching (De Beer \& Ramnarain, 2012). Studies show that learners in South Africa experience only limited instances of inquiry learning in the science classroom (Ramnarain, 2007; Rogan \& Aldous, 2005). Learners are taught facts, but do not develop the skills needed to discover how the natural world functions. Furthermore, inquiry-based teaching, when it does take place, is mainly teacher controlled, with learners involved primarily in analysing collected data and drawing conclusions.

This South African state of affairs is in sharp contrast to Finland, which has successfully transformed science education. This transformation offers valuable lessons for South Africa. With the simple act of putting on a white laboratory coat as they enter the science classroom in Finland, learners enter a different epistemological space, namely the world of science ${ }^{1}$. Through well-structured inquiry-learning activities, the Finnish teacher masterfully guides the learners on their journey of inquiry. Finnish teachers have a very good knowledge of the tenets of science (De Beer \& Ankiewicz, 2015). This use of CHAT illustrates the tensions that arise between the nodes in two different activity systems. Firstly, a tension exists within the community, where Finland is a monolingual society and learners learn in their mother tongue, in contrast to multilingual South Africa where English as medium of instruction is a second or third language. Another conflict among nodes is, for example, within the tools used. Whereas many South African classrooms are still characterised by teacher-centred, transmission mode teaching, most Finnish classrooms foreground inquiry learning.

Regarding rules (see Figure 4) we would like to highlight two aspects. The South African school science curriculum has been characterized the last two decades by constant changes. This has led to instability, with teachers feeling insecure. Finnish

\footnotetext{
${ }^{1}$ Observation by Josef de Beer, during a research visit to Helsinki, Finland, in 2014. In this particular case, white laboratory coats hung outside the classroom/ laboratory. Before the students entered the laboratory, they put on the laboratory coats, and it was interesting to note how the students assumed a different 'role' (division of labour) once they had done this, namely the role of a scientist.
} 
teachers are scholars, who all hold master's degrees (and a sizeable proportion hold PhDs), and who engage in classroom action research (Niemi, 2009; Sahlberg, 2009; Nelson, 2010; De Beer \& Ankiewicz, 2015). The selection process is rigorous. The relationship between teaching schools and university faculties of education in Finland results in very effective teacher education. Here we would like to emphasize how tensions in different nodes in the activity system explain the complexity within the object of the activity system.

CHAT as a research lens shows where tensions or "fracture lines" exist in and between activity systems. When studying Figure 4 , it is clear that several tensions arise that negatively impact science education in South Africa. This is further illuminated if the South African education system is juxtaposed with the Finnish education system.

CHAT is a barometer of tensions. To justify this statement, we will provide a few examples. The first example refers to tensions between the subject and the tools. The South African science curriculum prescribes learning tasks such as laboratory investigations and open-ended inquiries. The question arises, however, whether South African teachers are capable of providing such authentic learning experiences. In Finland, on the other hand, where all science teachers hold master's degrees the teachers have a very good understanding of the nature of science (Sahlberg, 2009; Niemi, 2009; Nelson, 2010). Whereas inquiry lessons in South Africa are probably the exception (in contrast to the predominant transmission-mode pedagogies), it is the rule in Finland.

A second example is the tension that exists between the object and the tools in the activity system. A culture of learning characterizes Finnish schools (Niemi, 2009; Sahlberg, 2009). Through well-structured inquiry-learning activities, the teacher masterfully guides learners on their journey of inquiry (De Beer \& Ankiewicz, 2014). Cell phone technology, tablets and the internet are effectively weaved into the lesson to mediate learning. South African schools, on the other hand, are often characterized by a poor culture of learning, under-resourced classrooms and limited agency on the part of the science teacher (De Beer \& Ramnarain, 2012). The authors, doing research in South African schools, have often observed teachers instructing learners to switch off their cell/smart phones. This technology offers opportunities for learning, even for simple tasks such as time keeping - an aspect that Finnish teachers put to good use.

A last example shows tensions associated with the division of labour. A trademark of Finnish education is that teachers are also scholars involved in classroom action research (Nelson, 2010; De Beer \& Ankiewicz, 2015). This is in stark contrast to South Africa, where a very small percentage of teachers are engaged in classroom action research. In similar way, Finnish teachers, in general, are critical and reflective practitioners, a practice that their South African counterparts often lack. 
Within the limited scope of such as paper, we cannot pay justice to the rich insights that can be distilled from using CHAT on an institutional plane. However, from the limited examples provided, it should be clear that when contrasting two systems (or institutions), CHAT can provide a good understanding of the activity systems by illuminating the multiple tensions that exist.

We would like to use a last example to illustrate the usefulness of CHAT in a complex society such as South Africa, and we would like to study the tertiary student \#FeesMustFall campaign of 2016, through such a lens.

\section{Learning from our leaders: The \#FeesMustFall student unrests}

South Africa has a long history of resistance, which often resulted in violence. During the liberation struggle, the African National Congress (ANC) mobilized people through public demonstrations (that often became violent). By focusing on the historical context in South Africa, it should therefore hardly be surprising that university students engaged in violent protests in 2015/ 2016, against the costs of university education. Although these students are referred to as the "born frees" (they were born after South Africa became a democracy in 1994), many of them were exposed to the stories of their parents, on how they fought for freedom. In essence the students used similar approaches to protest against the cost of university studies, and the Eurocentric curriculum (linked to the \#FeesMustFall, is also a call for the "decolonization of the curriculum"). They took to the streets, damaged property, ransacked businesses around the university campuses, and set several buildings on university campuses on fire, causing damage of millions of dollars.

In Figure 5 we look at the \#FeesMustFall student protests from a CHAT perspective on an institutional plane. The sub-activity system on the left focuses on campus management, and how institutional leaders look at the object of university education. The sub-activity system on the right focuses on the student bodies' perspectives on the object. Once again, the same "contradiction of control" that was visible in Figure 3 emerges in this activity system, and highlights the complexity of the object. 
Figure 5: Looking at the \#FeesMustFall student campaign from a Cultural-Historical Activity Theory perspective

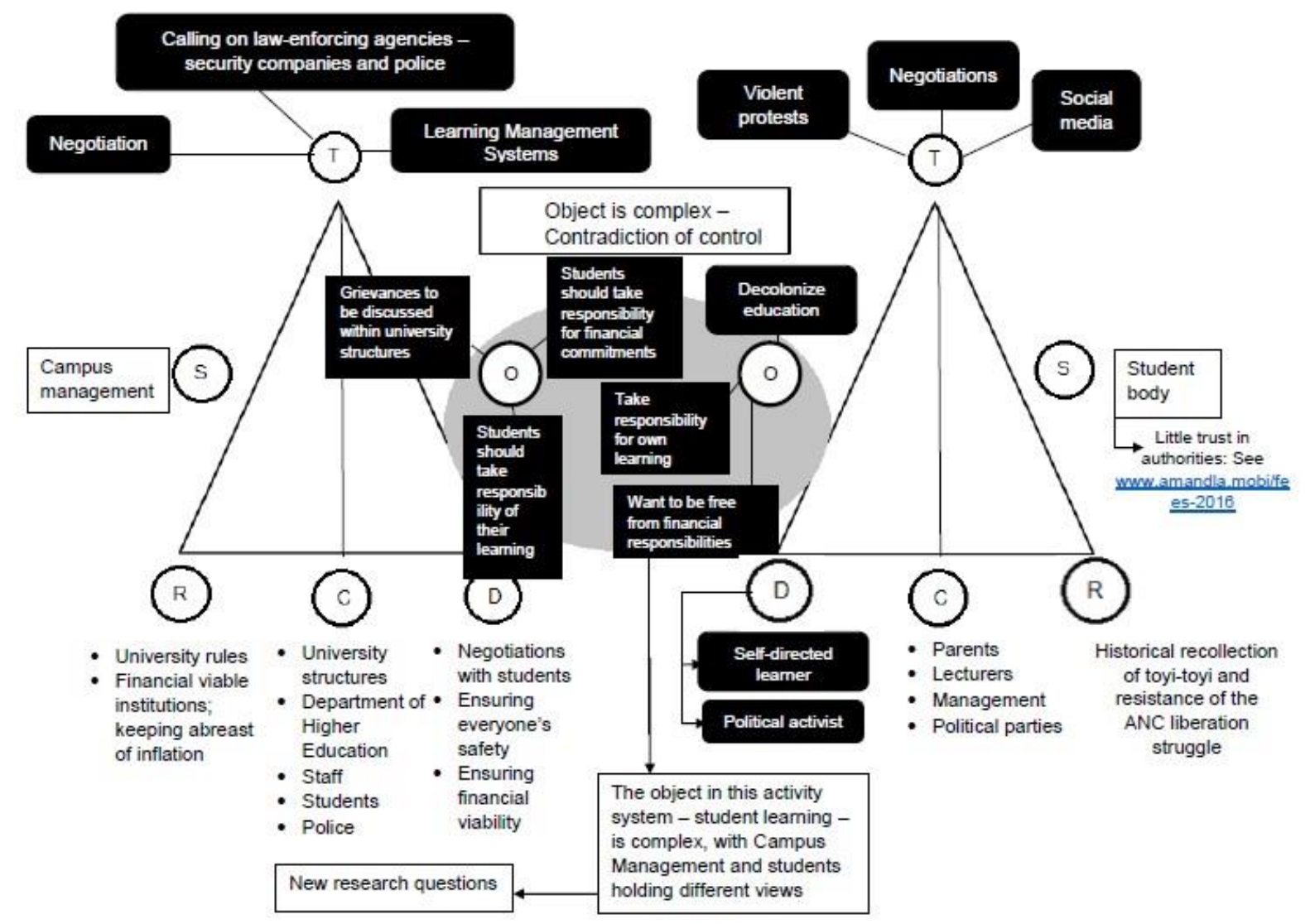

Source: Authors' own example, based on third-generation CHAT as developed by Engeström (2009)

Both university management and the student bodies view the object in the activity system as students being responsible for their own learning (self-directed learners), and successfully obtaining their qualifications. Students do take responsibility for their learning, but they would like to do so without the burden of financial stress. The students feel that, if they have access to free tertiary education, they can devote their energy to their studies, without the paralysing effect of financial worries. University management, on the other hand, sees student responsibility as also encompassing financial responsibility, e.g. student fees should be paid. Although universities do provide platforms for students to raise their grievances, students often find these platforms or structures inadequate. De Beer, Smith and Jansen (2009) also highlight that, on some university campuses, some students show mistrust in university management. The \#FeesMustFall, was a well-coordinated campaign, where students used the social media as tool, to get large numbers of students involved nationally. For weeks the protests on several of South Africa's campuses made headlines, and the whole country took notice. 
It is interesting to study this activity system from a tools perspective. Firstly, the student bodies were extremely effective in utilising social media to get national support for their campaign. However, in some cases Campus Management were equally successful in using Learning Management Systems to ensure that teaching and learning activities continued.

In Figure 5 we list negotiations as tools for both campus management and student bodies. The question can be ask why this was not successful. CHAT provides a unique gaze into this aspect if one considers the tensions between the rules and division of labour of student bodies and university managers (e.g. students assumed the role of political activists and engaged in militant behaviour such as toyi-toying, which closed the doors for negotiations). On the other hand, management, which has a mandate to ensure safety on university campuses, called on the services of lawenforcing agencies such as the police to try and contain the protests. The behaviour of both the student bodies and campus management resulted in an explosive and toxic atmosphere not conducive for negotiations.

As in Figure 3, the systemic tensions in the activity system explained above impacted on the object of the activity, and this once again emphasized the complexity of the object due to the contradiction of control. This example illustrates the use of CHAT in developing a more nuanced understanding of actors' behaviour in a post-truth society. CHAT considers the historical, cultural and socio-economic aspects that guide human behaviour, and shows that the problem of not having a common (unified) object in an activity system can lead to tensions with devastating results.

\section{Conclusion}

In this paper we showed how Cultural-Historical Activity Theory is a very applicable lens to use in South Africa, with its cultural diversity, socio-economic challenges and transformation agenda. CHAT has the potential to provide a robust meta-theoretical framework for understanding and analysing many areas of research and practice (Igira \& Gregory, 2009). CHAT offers a cross-disciplinary perspective for analysing human practices as development processes in which both individual and social levels are interlinked. We argue that CHAT is a flexible lens, which could be used on either a personal, interpersonal or institutional plane. In this paper we have focused on examples from both school and university education as activity systems. A common denominator between school and university is the need for self-directed learning in a complex $21^{\text {st }}$ Century. South Africa needs people who can adjust to new situations and who can take responsibility for their own learning. Much research into such practices nurturing self-directed learning is needed, and we argue that CHAT could be a useful lens to use in this regard.

A particular contribution of this paper is the focus on the object of an activity system as a complex phenomenon, due to what McNeil refers to as the "contradiction of control". The South African classroom is characterized by a diversity of people with different 
value systems (Beck \& Linscott's construct of "memes"), and this colliding perspectives could hinder education if not managed well. We also argue that this is an issue of international importance. As mentioned earlier on in this paper, many other countries, to various degrees, struggle with the same problems as South Africa. Using CHAT as a lens provides insight in the complexity of an activity system, identifying tensions that would otherwise not necessarily be visible. From this crucible could come workable solutions for a more just society.

\section{References}

Abd-el-khalick, F., Bell, R.L. and Lederman, N.G., 1998. The nature of science and instructional practice: making the unnatural natural. Science Education, 82(1), pp.417-436.

Beatty, I.D. and Feldman, A., 2009. Illuminating teacher change and professional development with CHAT. Proceedings of the NARST 2009 Annual Meeting.

Beck, D. and Linscott, G., 1991. The Crucible: Forging South Africa's future. Johannesburg: New Paradigm Press.

Centre for development and enterprise., 2011. Value in the classroom: the quantity and quality of South Africa's teachers. CDE In Depth Number 11. Johannesburg: CDE.

De Beer, J. and Ankiewicz, P., 2015. Re-imagining science teacher education in South Africa: lessons from Finland. Unpublished paper read at the HELTASA Conference, November 2015.

De Beer, J. and ramnarain, U., 2012. The implementation of the Physical and Life Sciences curricula: opportunities and Challenges. Research report prepared for the Department of Education.

De Beer, J., Smith, U. and Janden, C., 2009. 'Situated' in a separated campus - students' sense of belonging and academic performance: a case study of the experiences of students during a higher education merger. Education as Change, 13(1), pp.167-194.

Engeström, Y., 1987. Learning by expanding: An activity-theoretical approach to developmental research. Helsinki: Orienta-Konsultitl.

Engeström, Y., 2009. From learning environments and implementation to activity systems and expansive learning. Actio: an international Journal of Human Activity Theory, 2(1), pp.17-33.

Havnes, A., 2010. Cultural-Historical Activity Theory. In: Learning and Cognition: Theoretical Perspectives - Learning (pp 491 - 497).

Igira, F.T. and Gregory, J. 2009. Cultural Historical Activity Theory. IGI Global.

Knowles, M., 1975. Self-directed learning: A guide for teachers and learners. Chicago, IL: Follett.

Luria, A. R., 1981. Wertsch, J.V. (ed). Language and cognition. New York: Wiley Interscience.

McNeil, L.M., 2013. Contradictions of control: School structure and school knowledge. Routledge.

Nelson, B.J., 2010. Finland education and PISA: a review of literature. 
Niemi, H., 2009, June. Why Finland on the top? Reflections on the reasons for the Pisa success. In 3rd Redesigning Pedagogy International Conference.

Ramnarain, U.D. 2007. A study of the implementation of scientific investigations at grade 9 with particular reference to the relationship between learner autonomy and teacher support. Unpublished doctoral dissertation, University of KwaZulu-Natal.

Reitsma, G., Guglielmino, L. and Mentz, E., 2012. Faculty development to promote self-directed learning: The North-West University Approach. International Journal of Self-Directed Learning, 9(2), pp.44-51.

Rogan, J. and Aldous, C., 2005. Relationships between the constructs of a theory of curriculum implementation. Journal of Research in Science teaching, 42(3), pp.313-336.

Rogoff, B. 1995. Apprenticeship in thinking: Development in social context. Cambridge: Harvard University Press.

Sahlberg, P., 2009. A short history of educational reform in Finland. Unpublished paper.

Vygotsky, L.S., 1978. Mind in society. London: Harvard University Press.

Wertsch, J.V., 1998. Mind as action. Oxford: Oxford University Press. 